\title{
Exploring Emotion and Their Antecedents in Indonesian Young Children
}

\author{
Lucia Voni Pebriani, Laila Qodariah \\ Faculty of Psychology, Universitas Padjadjaran, Bandung, Indonesia
}

Corresponding e-mail: lucia.voni@unpad.ac.id

\begin{abstract}
Emotional development begins early in life. From birth, children rapidly develop their abilities to experience and express different emotions. The foundations of social competence that are developed in the first five years impact the children's later ability to functionally adapt in school and to form successful relationships throughout life. Yet, emotional development often receives relatively less recognition as a core emerging capacity in early childhood, including in Indonesia. However, if we can develop an understanding of emotional development in early childhood life, this study will be able to support parents and providers of early care and education to deal with common age-appropriate behavioral challenges. This study focused on the antecedents of the primary and self-conscious emotions in early childhood (0-6 years old). The survey was conducted using 120 samples from Bandung, Jakarta, and Medan, 60 participants of 0-2 years children old and 60 participants of 3-6 years old children. The result of the research is the basic emotion such as happy, sad, angry, fear, disgust, interested and surprised have emerged from 0-2 years old and continue to emerge for the next years. While self-conscious emotion that includes empathy, jealous, shame, and proud emerge more in children above 2 years old. It's the moment when the children have a sense of self, and an ability to compare his/her self to social situation around them. Almost all antecedents for each basic emotion and self-conscious emotion are from external stimulus, either nonsocial (e.g., loud noise) or social (e.g., separation from a loved one). Further, research can be continued by correlating the children's answers and parents' responses. It can also be enriched with the data about cultural background and socioeconomic status to explain the differences between the antecedents of each emotion in Indonesia and former research. The number of participant for each age category also has to be considered.
\end{abstract}

Keywords: Emotional Development, Antecedent of Emotion, Early Childhood

\section{INTRODUCTION}

Emotional development begins early in life. From birth, children rapidly develop their abilities to experience and express different emotions. The foundations of social competence that are developed in the first five years impact the children's late ability to functionally adapt in school and to form successful relationships throughout life. Yet, emotional development often receives relatively less recognition as a core emerging capacity in early childhood, including in Indonesia.

The benefit of this research is to provide knowledge for parents especially in Indonesia, about what events or situations that make their children show an emotion. If the parents have knowledge about it, they can help the children to enhance their development of emotional understanding, by identifying their emotions and their antecedents. The emotional understanding is the first step of emotional competence.

The children's emotional development provides them a sense of who they are in the world, how they learn, and helps them to establish quality relationships with others. It is what drives an individual to resolve conflicts, gain confidence and reach goals. Building a strong emotional foundation as a child will help the child to thrive and obtain happiness in life, handle the stress and persevere with difficult times in their lives as an adult. Parents and educators must learn to notice the children's emotional cues so that they can help the children to identify their emotions. They can also be the behavior model for the children. They show 
consideration to the children's feelings, desires and needs, also show interest in the children's daily activities, respect the children's point of view, express pride in the children's accomplishment; provide encouragement and support during the moment of stress.

\section{LITERATURE REVIEW}

Emotion is feeling or affect that occur when people are in a state or an interaction that is important to them, especially that influences their well-being. In many instances, emotions involve people's communication with the world. Although emotion consists of more than communication, in infancy the communication aspect is at the forefront of emotion (Lewis, 2008).

An expert on infant emotional development, Lewis (2008) distinguishes between primary emotions and self-conscious emotions. Primary emotions are emotions that are present in humans and other animals, including surprise, interest, joy, anger, sadness, fear, and disgust. In Lewis' classification, self-conscious emotions require self-awareness that involves consciousness and a sense of "me." This emotion includes jealousy, empathy, embarrassment, pride, shame, and guilt. Lewis argues that these self-conscious emotions occur for the first time at some point in the second half of the first year through the second year. Some experts on emotion call self-conscious emotions such as embarrassment, shame, guilt, and pride as "other-conscious emotions" because they involve the emotional reactions of others when they are generated (Santrock ,2014).

If we talk about emotion, that will be an elicitor/antecedent, state, and experiences of emotion (Lewis, 2008). Emotional elicitor is some stimulus events that must trigger a change in the state of organism. The trigger may either an external or internal stimulus. External antecedents may be nonsocial (e.g., loud noise) or social (e.g., separation from a loved one). Internal antecedents may range from changes in specific physiological states to complex cognitive activities. Since it is obviously much harder to identify and manipulate an internal antecedent than an external one, it is not surprising that most research deals with external stimuli; that is, it attempts to determine precisely which features of the antecedent activate the emotion. Since each person has different perception about some stimuli, it will also be different in states and experience.

\subsection{Developmental Changes of Emotion}

Based on a model of the emergence of different emotions by Lewis (2008), infants start to smile to show happiness when confronted with familiar events, such as faces of people they know. Around the middle of the first year, infants laugh more when interacting with familiar people. Between 8 and 10 months, infants more often interrupt their play with an interesting toy to relay their delight to an attentive adult (Berk, 2012).

By 3 months, sadness emerges, especially around the withdrawal of positive stimulus events.

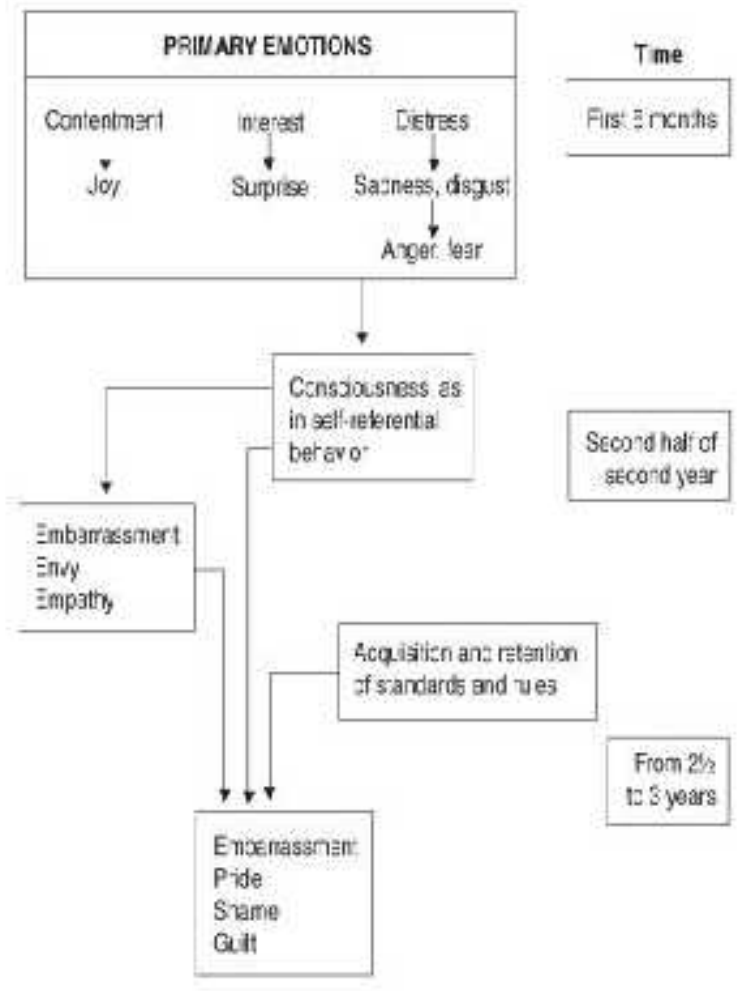

Figure 1. Development of emotions over the first 3 years of life

Three-month-old children show sadness when their mothers stop interacting with them. Expressions of sadness also occur in response to pain, removal of an object, and brief separations, they are less common than anger (Berk, 2012). In contrast, sadness occurs often when infants are deprived of a familiar, loving caregiver or when caregiver-infant communication is seriously disrupted. Disgust also appears in its primitive form-a spitting out and getting rid of unpleasanttasting objects placed in the mouth. 
Anger has been reported to emerge between 4 and 6 months (Lewis, 2008). Anger is manifested when children are frustrated-when their hands and arms are pinned down and they are prevented from moving. Lewis et al (1990) have shown anger in 2 -month-old infants when a learned instrumental act was removed. This study demonstrates the earliest known emergence of anger. Their anger is particularly intense when a caregiver from whom they have come to expect warm behavior causes discomfort. Older infants also react with anger in a wider range of situations-when an interesting object or event is removed, an expected pleasant event does not occur, their arms are restrained, the caregiver leaves for a brief time, or they are put down for a nap (Lewis, 2008).

Fearfulness seems to emerge still later. Schaffer (1974) has shown that in order for children to show fear, they must be capable of comparing the event that frightens them with some other events (Lewis, 2008). Fear occurs when the face is found to be discrepant or unfamiliar relative to all other faces that the child remembers. Children's ability to show fearfulness, therefore, does not seem to emerge until this comparison ability emerges. Children begin to show this behavior at about 7-8 months, although it has been reported by some to occur even earlier, especially in children who seem to be precocious, like anger, fear rises during the second half of the first year into the second year ( Berk, 2012). Older infants hesitate before playing with a new toy, and newly crawling infants soon back away from heights. But the most frequent expression of fear is to unfamiliar adults.
Surprise appears in the first 6 months of life. Children show surprise when there are violations of expected events; for example, when infants see a midget (a small adult) walking toward them, they are reported to show interest and surprise rather than fear or joy (Lewis, 2008). Surprise can be seen either when there is violation of expectancy or as a response to discovery, as in an "Aha!" experience. Surprise can reflect either a violation or a confirmation of expectancy.

Lewis et al (1989) have shown that the emergence of embarrassment only takes place after consciousness or self-recognition occurs (Lewis, 2008). By age 3, self-conscious emotions are clearly linked to self-evaluation. Preschoolers show much more pride when they succeed in difficult rather than easy tasks and much more shame when they fail simple rather than hard tasks (Berk, 2014).

\section{METHOD}

The survey was conducted using 120 samples from Bandung, Jakarta and Medan, 60 participants of 0-2 year's children old and 60 participants of 3-6 years old children. They and their parents were asked about the antecedent and expression of primary and self-conscious emotion. Their answer about antecedent of each emotion was coded.

\section{RESULT AND DISCUSSION}

The result of primary emotion is shown in Table 1 And the result of self-conscious emotion is shown in Table 2 .

Table 1. Primary Emotion and Its Antecedents in 0-2 years old children and 3-6 years old children

\begin{tabular}{|l|l|l|}
\hline Emotion & \multicolumn{1}{|c|}{ 0-2 years old } & \multicolumn{1}{|c|}{ 3-6 years old } \\
\hline \multirow{5}{*}{ Surprised } & $66,7 \%$ loud noise & $38,6 \%$ loud noise \\
\cline { 2 - 3 } & $\begin{array}{l}33,33 \% \text { sudden action } \\
\text { when interaction with others }\end{array}$ & $\begin{array}{l}38,46 \% \text { watch horror } \\
\text { film }\end{array}$ \\
\cline { 2 - 3 } & & $\begin{array}{l}32,30 \% \text { sudden action } \\
\text { when interaction with } \\
\text { others }\end{array}$ \\
\hline
\end{tabular}


Table 1. Cont.

\begin{tabular}{|c|c|c|}
\hline \multirow{5}{*}{ Interested } & $71,43 \%$ see a new thing & $\begin{array}{l}55,44 \% \text { see a new } \\
\text { thing }\end{array}$ \\
\hline & $14,29 \%$ see a food & $\begin{array}{l}15,15 \% \text { hear a song, } \\
\text { music, and people talking }\end{array}$ \\
\hline & $14,30 \%$ interaction with others & $\begin{array}{l}12,12 \% \text { interaction with } \\
\text { others }\end{array}$ \\
\hline & & $9,09 \%$ see a food \\
\hline & & $\begin{array}{l}9,09 \% \text { see a favorite } \\
\text { thing }\end{array}$ \\
\hline \multirow{5}{*}{ Happy } & $50 \%$ social interaction & $\begin{array}{l}30 \% \text { social } \\
\text { interaction }\end{array}$ \\
\hline & $33 \%$ get something & $\begin{array}{l}26,4 \% \text { their needs } \\
\text { fulfilled }\end{array}$ \\
\hline & $17 \%$ play & $16,67 \%$ play \\
\hline & & $\begin{array}{l}14,17 \% \text { get } \\
\text { something }\end{array}$ \\
\hline & & $\begin{array}{l}8,82 \% \text { get some } \\
\text { achievement }\end{array}$ \\
\hline \multirow{3}{*}{ Angry } & $\begin{array}{l}71,43 \% \text { negative interaction } \\
\text { with others }\end{array}$ & $\begin{array}{l}71,43 \% \text { negative } \\
\text { interaction with others }\end{array}$ \\
\hline & $28,57 \%$ delay of gratification & $\begin{array}{l}22,2 \% \text { can't fulfill } \\
\text { their needs }\end{array}$ \\
\hline & & $\begin{array}{l}3,7 \% \text { delay of } \\
\text { gratification }\end{array}$ \\
\hline \multirow{5}{*}{ Sad } & $\begin{array}{l}33 \% \text { left temporary by significant } \\
\text { person }\end{array}$ & $\begin{array}{l}23 \% \text { can't get what they } \\
\text { want }\end{array}$ \\
\hline & $30 \%$ can't get what they want & $\begin{array}{l}20 \% \text { left temporary by } \\
\text { significant person }\end{array}$ \\
\hline & & \\
\hline & $21 \%$ got an unpleasant action & $\begin{array}{l}37 \% \text { got the } \\
\text { unpleasant action }\end{array}$ \\
\hline & $16 \%$ feel sick & $20 \%$ feel sick \\
\hline \multirow{6}{*}{ Fear } & $24 \%$ social situation & $61,67 \%$ animal \\
\hline & $20 \%$ loud noise & $\begin{array}{l}38,33 \% \text { unanticipated } \\
\text { event (locked in the } \\
\text { room, dark room } \\
\text { suddenly) }\end{array}$ \\
\hline & $20 \%$ animal & \\
\hline & $12 \%$ doll & \\
\hline & $\begin{array}{l}12 \% \text { unanticipated event (locked } \\
\text { in the room, dark room } \\
\text { suddenly) }\end{array}$ & \\
\hline & $12 \%$ see something unusual & \\
\hline
\end{tabular}


Table 1. Cont

\begin{tabular}{|l|l|l|}
\hline \multirow{4}{*}{ Disgust } & $30 \%$ dirty environment & $\begin{array}{l}45 \% \text { dirty } \\
\text { environment }\end{array}$ \\
\cline { 2 - 3 } & $20 \%$ feces & $40 \%$ animal \\
\cline { 2 - 3 } & $20 \%$ nasty food & $10 \%$ nasty food \\
\cline { 2 - 3 } & $20 \%$ sticky and hairy texture & $\begin{array}{l}5 \% \text { sticky and hairy } \\
\text { texture }\end{array}$ \\
\cline { 2 - 3 } & $10 \%$ dirty clothes & \\
\hline
\end{tabular}

The result shows that both categories of children can feel the primary emotions, which are fear, happy, sad, disgust, and surprised. For self-conscious emotions such as empathy, shy, guilt, and proud, more than $30 \%$ of 3-6 years old children can feel it but only less than 30\% 0-2 years old children can do. It's as same as the theory of self-conscious emotion by Lewis (1997) that this emotion emerges at 2 years old and more. Self-conscious emotion also appears if they have the consciousness and a sense of "me" that starts to arise at 2 years old.

The significant antecedent of sad in 0-2 year's children is being left temporary by their significant others (33\%), while in 3-6 years old, it is the inability to get what they want. This result is as same as the Lewis research that 3 month old children feel sad if their significant others stop the interaction with them or when interaction has been disturbed or brief separation (Lewis, 2008). This result can also be described by attachment theory by Bowlby (Santrock, 2014) that attachment starts to form at less than 2 years old, so being left temporary by significant person will emerge sadness. The antecedent of sad that emerges before 2 years old and still emerges after 3 years old, is losing the ability to maintain positive stimuli, such as things or events.

The cause of fear in 0-2 years old children is social situation, loud noise, unanticipated events, and seeing something unusual. In 3-6 years old children, the significant cause of fear is animal and unanticipated events like dark room, or suddenly locked in the room. The significant antecedent of fear in 0-2 years old children is unfamiliar faces of adult. They can differ familiar and unfamiliar faces clearly. Before 1 year old, the most frequent fear expression of an infant involves stranger anxiety, in which an infant shows a fear to a stranger, that emerges gradually. It first appears at about 6 month, and more intense at age 9 month and reaching peak toward the end of the first year of life and then decreasing thereafter.

Disgust emotion appeared in both age categories of children. It appeared when the children were at the dirty environment. Another antecedent in 0-2 years old and 3-6 years old children are the feces, stale food and dirty clothes. The antecedent of fear that only appears in 3-6 years old children is animal. Based on the research, disgust appears in its primitive form-a spitting out and getting rid of unpleasant-tasting objects placed in the mout. But for some reason, dirty thing or dirty environment are disgusting due to our knowledge of the nature and origin of the objects. The disgusting nature of these later items must be explicitly taught (Bloom, 2004). One way that children's disgust beliefs for animals might change is via vicarious learning: by observing others responding to the animal with disgust (Goodman, 2014). 
Table 2. Self Conscious Emotion and Its Antecedents in 0-2 years old children and 3-6 years old children

\begin{tabular}{|c|c|c|}
\hline Emotion & 0-2 years old & 3-6 years old \\
\hline \multirow{5}{*}{ Jealous } & $\begin{array}{l}63 \% \text { mother is closed with } \\
\text { others }\end{array}$ & $\begin{array}{l}33 \% \text { father is closed with } \\
\text { others }\end{array}$ \\
\hline & $\begin{array}{l}21 \% \text { father is closed with } \\
\text { others }\end{array}$ & $\begin{array}{l}21,73 \% \text { mother is closed } \\
\text { with others }\end{array}$ \\
\hline & $\begin{array}{l}10,53 \% \text { rivalry to get } \\
\text { the attention }\end{array}$ & $\begin{array}{l}21,73 \% \text { members of } \\
\text { family are closed with } \\
\text { others }\end{array}$ \\
\hline & $\begin{array}{l}5,26 \% \text { members of } \\
\text { family are closed with } \\
\text { others }\end{array}$ & $\begin{array}{l}16,30 \% \text { friends are closed } \\
\text { with others }\end{array}$ \\
\hline & & $5,43 \%$ rivalry to get attention \\
\hline \multirow{3}{*}{ Empathy } & $60 \%$ see others hurt or sad & $\begin{array}{l}73,68 \% \text { see others hurt or } \\
\text { sad }\end{array}$ \\
\hline & $\begin{array}{l}20 \% \text { people ask for } \\
\text { something }\end{array}$ & $\begin{array}{l}21,6 \% \text { people don't have } \\
\text { anything }\end{array}$ \\
\hline & $\begin{array}{l}20 \% \text { see people don't } \\
\text { have anything }\end{array}$ & $\begin{array}{l}5,26 \% \text { people ask for } \\
\text { something }\end{array}$ \\
\hline \multirow{4}{*}{ Shame } & $\begin{array}{l}53,86 \% \text { meet new } \\
\text { people }\end{array}$ & $42,86 \%$ meet new people \\
\hline & $\begin{array}{l}30,77 \% \text { interaction with } \\
\text { familiar people }\end{array}$ & $\begin{array}{l}35,71 \% \text { performing } \\
\text { ability }\end{array}$ \\
\hline & $15,35 \%$ appearance & $\begin{array}{l}7,14 \% \text { interaction with } \\
\text { familiar people }\end{array}$ \\
\hline & & $\begin{array}{l}7,14 \% \\
\text { appearance }\end{array}$ \\
\hline \multirow{5}{*}{ Prestige } & $\begin{array}{l}50 \% \text { people give them } \\
\text { something }\end{array}$ & $33,33 \%$ asked for apologize \\
\hline & $\begin{array}{l}50 \% \text { the others has better } \\
\text { thing }\end{array}$ & $\begin{array}{l}33,33 \% \text { the others has better } \\
\text { things }\end{array}$ \\
\hline & & $\begin{array}{l}11,11 \% \text { people give them } \\
\text { something }\end{array}$ \\
\hline & & $\begin{array}{l}11,11 \% \text { be acquainted with } \\
\text { new people }\end{array}$ \\
\hline & & $\begin{array}{l}11,11 \% \text { playing with your } \\
\text { children }\end{array}$ \\
\hline
\end{tabular}


Table 2. Cont

\begin{tabular}{|c|c|c|}
\hline \multirow{4}{*}{ Guilty } & $\begin{array}{l}37,5 \% \text { doing negative } \\
\text { action to others }\end{array}$ & $\begin{array}{l}32,14 \% \text { doing negative } \\
\text { action to others }\end{array}$ \\
\hline & $\begin{array}{l}25 \% \text { told by others that } \\
\text { he/she has done something } \\
\text { wrong }\end{array}$ & $\begin{array}{l}17,85 \% \text { told by others that } \\
\text { he/she has done something } \\
\text { wrong }\end{array}$ \\
\hline & $\begin{array}{l}25 \% \text { doing something } \\
\text { wrong purposefully }\end{array}$ & $\begin{array}{l}46,42 \% \text { doing something } \\
\text { wrong purposefully }\end{array}$ \\
\hline & $\begin{array}{l}12,5 \% \text { doing something } \\
\text { wrong accidentally }\end{array}$ & $\begin{array}{l}3,5 \% \text { doing something } \\
\text { wrong } \\
\text { accidentally }\end{array}$ \\
\hline
\end{tabular}

The different result between the $0-2$ years old children and the 3-6 years old children appears in jealousy. 0-2 years old children get jealous when their mothers are closed with other persons, while of 3-6 years old children get jealous when their fathers are. The antecedent that only appears in 3-6 years old is a situation when their friends gather without them. The same antecedent of jealousy in both age categories is rivalry situation. Several lines of research indicate that very young children are sensitive to the loss of parental attention to another. Dunn (1988) has reported that toddler and preschool children were very atunned to the interaction between their parents and their siblings and would often try to disrupt the ongoing interaction. The few extant studies have documented that children as young as 1 year of age were sensitive to maternal attention directed toward an infant-size doll, newborn infant, or an unfamiliar peer.

The same significant cause of feel interested appears in both categories, that they feel interested when they see the new thing. While the $0-2$ years children are also feel interested to food and others concrete things, the 3-6 years old children feel interested to music, song or the sound of people talking.

Both categories of children feel surprised when they hear loud noise and see new things. Surprise also appears in the first 6 months of life. Children show surprise when there are violations of expected events; for example, when infants see a midget (a small adult) walking toward them, they are reported to show interest and surprise rather than fear or joy (Lewis,2008). Surprise can be seen either when there is violation of expectancy or as a response to discovery, as in an "Aha!" experience. Surprise can reflect either a violation or a confirmation of expectancy.

The same antecedent of happy emotion in both age categories is also social interaction and playing. The antecedent that only appears in 3-6 years old children is a situation when they can achieve something. Based on the research, infants start to smile and appear to sho excitement/happiness when confronted with familiar events, such as faces of people they know or even unfamiliar faces ( Lewis, 2008). Around the middle of the first year, infants smile and laugh more when interacting with familiar people.

Between 8 and 10 months, infants more often interrupt their play with an interesting toy to relay their delight to an attentive adult (Berk, 2012). But for the older children (3-6 years old) when sense of self has been appeared, achievement also part of self esteem. (Santrock, 2014)

The children get angry when they have a negative interaction with others, delay of gratification, and their needs can't be fulfilled on time. Anger is manifested when children are frustrated. The anger of older children is particularly intense when a caregiver whom they expect to give warmth causes discomfort. Older infants also react with anger in a wider range of situations-when an interesting object or event is removed, an expected pleasant event does not occur, their arms are restrained, the caregiver leaves for a brief time, or they are put down for a nap ( Berk,2012).

Empathy appears when they see others look sad or hurt, or when the others ask them something they don't have or when people ask for 
something. Lewis et. al (Berk, 2012) have shown that the emergence of empathy only takes place after consciousness or self-recognition occurs. Along with the development of self-other differentiation, perspective taking, and emotion regulation during the second year of life, however, there appears to be a transformation from concern for the self to a capability for concern for the other (Berk, 2012),

The children feel shame when they meet new people, interact with unfamiliar people, and when they wear particular clothes. The reason for feeling shame that only appears in 3-6 years old is a situation when they have to perform their ability.

By age 3, self-conscious emotions are clearly linked to self-evaluation (Berk 2012).

Preschoolers show much more pride when they succeed in difficult rather than easy tasks and much more shame when they fail simple rather than hard tasks (Berk,2012).

The same antecedent of prestige in both categories is a situation when others has better thing. The difference is, $0-2$ years children old feel proud when people give them something, while in 3-6 years old feel proud when they were instructed to apologize. 3-6 years old children have more antecedent than 0-2 years old children, such as a situation when they are given something by others, they have to introduce themselves to others, and they play with younger kids. Santrock (2014) said that start from 2-4 years old, children have more cause and consequences of their emotion. The same fact was also found in Indonesian children. From 3 years old, they start to learn and do social play (Santrock (2014), so interaction with others and response from others influence their self esteem that is manifested in prestige.

\section{CONCLUSIONS AND LIMITATION}

The result of the research is basic emotion such as happy, sad, angry, fear, disgust, interested, and surprised have emerged from $0-2$ years old and continue to emerge in the next years. While selfconscious emotion that includes empathy, jealous, shame, and proud emerge more in children above 2 years old. It's the time when the children have sense of self, and can compare his/her self to social situation around them. Almost all antecedents for basic emotion and self-conscious emotion are from external stimulus, either nonsocial (e.g., loud noise) or social (e.g., separation from a loved one). The limitation of this research is it can't explain the differences between the antecedent of each emotion in Indonesia and the former research result. Further, research can be continued by correlating the children's answers and parents' responses. It can also be enriched with the data about cultural background and socioeconomic status to explain the differences between the antecedents of each emotion in Indonesia and former research. The number of participant for each age category also has to be considered.

\section{ACKNOWLEDGEMENTS}

This research was done with the funding from Department of Child Developmental, Faculty Of Psychology, Universitas Padjadjaran Bandung. Thank you also for the student of Developmental Psychology 1 for their help to gain the data from parents and child. I also thank Dra. Marisa F.Moeliono, M.Pd for the discussion and Vidya Anindita and Mitha for categorizing and coding the data.

\section{REFERENCES}

Berk, Laura. 2012. Child Development

Goodman, Sherryl. (2014). The Effect of Disgust and Fear Modeling on Children's Disgust and Fear for Animals. Journal of Abnormal Psychology.

Santrok, John. (2014). Child development- Thirteen Edition. Mc-Graw Hill; New York

McDonald, Nicole et al. The Development of Empathy: How, When, and Why: University of Miami Department of Psychology. USA

Misheva, Vessela. Shame and Guilt: The Social Feeling in Sociological Perspective. Published in Interaction on the Edge - proceedings from the 5th GRASP conference, $p$ 128-142

Lewis, Michael et.al. (2008). Handbook of Emotion. The Guilford Press. New York London

Volling, Brenda et.al. (2002). Regulation in Context: The Jealousy Complex between Young Siblings and Its Relations with Child and Family Characteristics. 